\title{
UNIVERSITY OF ROME CARBON-14 DATES XIV
}

\author{
M ALESSIO, F BELLA, S IMPROTA,
}

Istituto di Fisica, Università di Roma

\section{G BELLUOMINI, G CALDERONI, C CORTESI, and B TURI \\ Istituto di Geochimica, Università di Roma}

This list includes dates measured from January 1974 to June 1975 with previously described $\mathrm{CO}_{2}$ proportional counters (Alessio et al, 1970b). All archaeologic and geologic samples except for Arslantepe series come from Italian territory. Chemical apparatus for $\mathrm{CO}_{2}$ preparation and purification is unchanged (Alessio et al, 1970b). Data recording devices have recently been replaced with integrated circuits built entirely at the Lab. The logic of the circuitry was also modified to provide more stable devices and a higher relative figure of merit $\mathrm{A} / \sqrt{\mathrm{B}}$ of each counter $(\mathrm{A}=$ net activity of modern standard, $\mathrm{B}=$ background). Consequently, the resolution of age measurements has increased appreciably. Present values of $\mathrm{A} / \sqrt{\mathrm{B}}$ for the 4 counters in use are shown in Table 1 .

TABLE 1

\begin{tabular}{ccc}
\hline & $\begin{array}{c}\text { Volume } \\
\text { Counter }\end{array}$ & \begin{tabular}{c}
$\mathrm{A}$ \\
\cline { 3 - 3 }
\end{tabular} \\
\hline 1 & 1.5 & 10.4 \\
2 & 1.0 & 9.2 \\
3 & 1.0 & 7.1 \\
4 & 0.5 & 3.3 \\
\hline
\end{tabular}

Collagen from human and animal bones was dated for the first time. Pretreatment and collagen extraction are carried out as follows: when possible, only compact bone tissue is used. Bone bits are first cleaned both by hand and with $5 \% \mathrm{HCl}$; then collagen is freed from bone structure by cold $\mathrm{N} \mathrm{HCl}$ under continuous stirring, recovered by centrifugation, washed to eliminate $\mathrm{PO}_{4}{ }^{3--}$, and dried. Finally, the collagen is carbonized with conc $\mathrm{H}_{2} \mathrm{SO}_{4}$ before combustion in oxygen stream.

Charcoal and wood samples underwent standard pretreatment by boiling with 5 to $10 \% \mathrm{HCl}$; $\alpha$-labeled samples were given additional leaching with $2 \mathrm{~N} \mathrm{NaOH}$.

The activity of our modern standard, wood grown near Rome between 1949 and 1953, is checked repeatedly with $95 \%$ activity of NBS oxalic acid and measurements agree within $1 \sigma$. For each sample of $\mathrm{CO}_{2}$, the counting rate was corrected according to mass-spectrometrically measured ${ }^{13} \mathrm{C} /{ }^{12} \mathrm{C}$ ratio as described previously (Alessio et al, 1969). Dates are reported in conventional radiocarbon years, using Libby half-life of $5568 \pm 30 \mathrm{yr}$, with 1950 as the standard year of reference. When requested, dates are corrected according to Ralph et al (1973). 
CHECK SAMPLES

At our Lab proportional counting and benzene scintillation methods are mutually checked from time to time. Ages of various samples determined by scintillation method and remeasured by proportional counters are compared in Table 2. Results agree within $3 \sigma$.

TABLE 2

\begin{tabular}{lccl}
\hline & $\begin{array}{c}{ }^{14} \mathrm{C} \text { age-CO} \\
\text { proportional } \\
\text { counting method }\end{array}$ & $\begin{array}{c}{ }^{14} \mathrm{C} \text { age-liquid } \\
\text { scintillation } \\
\text { method }\end{array}$ & \multicolumn{1}{c}{ Refs } \\
\hline Rample $694 \alpha$ & $2330 \pm 50$ & $2230 \pm 50$ & R, 1975, v 17, p 316 \\
R-990 & $2960 \pm 50$ & $3000 \pm 50$ & R, 1975, v 17, p 318 \\
R-914a & $3610 \pm 50$ & $3310 \pm 100$ & R, 1975, v 17, p 321 \\
R-1023 $\alpha$ & $<150$ & $370 \pm 60$ & R, 1975, v 17, p 324 \\
R-980 & $1210 \pm 50$ & $1440 \pm 50$ & R, 1975, v 17, p 326 \\
R-810 $\alpha$ & $<150$ & $<150$ & To be pub \\
\hline
\end{tabular}

ACKNOWLEDGMENTS

We thank Consiglio Nazionale delle Ricerche for partial financial support. We also wish to thank our technicians for their fine work: A Fruscalzo for mass-spectrometric measurements, and B Petrocchi for activity measurements. We are indebted to $\mathrm{U}$ Nonno and $\mathrm{L}$ Ruotolo for their valuable help in sample preparation.

\section{SAMPLE DESCRIPTIONS}

I. ARCHAEOLOGIC AND HISTORIC SAMPLES

$$
\text { A. Italy }
$$

\section{Lago di Monate, pirogue series}

\section{R-854 $\alpha$. Monate Pirogue 2}

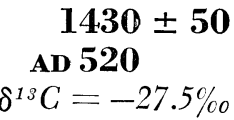

Fairly preserved wood from pirogue discovered in August 1971 in $\mathrm{N}$ area of Monate Lake, $6 \mathrm{~m}$ water depth, Comm Travedona-Monate,

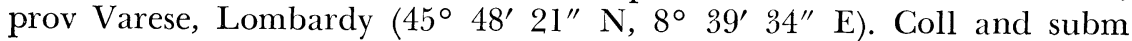
1971 by Sopr Antichità Lombardia, Milan. Comment: date agrees with F-63, for the same pirogue ( $R, 1974, \mathrm{v} 16, \mathrm{p} 13)$. No information has been provided on pirogue typology.

\section{R-855 $\alpha$. Monate 2a}

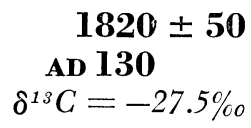

Wood fragments found near Pirogue $2,6 \mathrm{~m}$ water depth, $\mathrm{N}$ area Monate Lake. Comment: ${ }^{14} \mathrm{C}$ age shows unid. older wreck.

General Comment: wood from other pirogue named Monate I, subm by Sopr Antichità Lombardia, were dated: F-62, $940 \pm 75$ (R, 1974, v 16, p 13). 


\section{R-847 $\alpha$. Gravellona Toce, boat}

AD $>1800$

$\delta^{1 s} \mathrm{C}=-26.9 \%$

Fairly preserved wood, plank remains of a boat found partly buried in compact silty clayey sediments, ca $4 \mathrm{~m}$ depth, right bank and partly protruding into Rio Inferno at "La Baldina", $100 \mathrm{~m}$ from junction of Toce R, Lago Maggiore right tributary, N Gravellona Toce, prov Novara, Piedmont $\left(45^{\circ} 56^{\prime} 13^{\prime \prime} \mathrm{N}, 8^{\circ} 25^{\prime} 55^{\prime \prime} \mathrm{E}\right)$. The flat-bottomed boat, $1.30 \mathrm{~m}$ wide and $5 \mathrm{~m}$ long, was discovered 1955 by $\mathrm{G}$ Cribich and recovered by $\mathrm{C}$ and P Merletto et al, Gravellona Toce. Subm 1971 by F Rittatore Vonwiller, Gabinetto Paleont, Univ Milano. Comment: as Maggiore Lake still occupied above territory ca 1st century AD, boat was considered buried in old lacustrine sediments; ${ }^{14} \mathrm{C}$ date instead id a modern boat possibly buried by Toce flood deposits.

\section{Selvazzano pirogue series}

In 1972 sand quarrying revealed 2 large pirogues in Bacchiglione $\mathrm{R}$ bend at Il Porto near Selvazzano bridge ca $9 \mathrm{~km}$ WSW Padova, Veneto

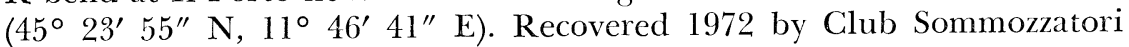
Padova, Sez Archeol, for Sopr Antichità delle Venezie, Padova; subm 1972 (Club S P, 1976).

\section{R-917 $\alpha$. Selvazzano Pirogue 1}

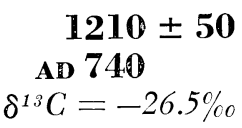

Heavily darkened wood from sternless monoxilous Pirogue 1 (Find B), $8.92 \mathrm{~m}$ long, max diam $1 \mathrm{~m}$, cut out of oak trunk. Pirogue was submerged across river, water depth 5 to $8 \mathrm{~m}$, partly resting on Pirogue 2, with stem buried in bottom sediments at middle river-bed. Comment: $5 \%$ HCl pretreatment disclosed only abundant $\mathrm{Fe}^{++}$and fulvic acids; abundant humic fraction was extracted by $.2 \mathrm{~N} \mathrm{NaOH}$.

\section{R-918 $\alpha$. Selvazzano Pirogue 2}

$$
\begin{gathered}
1200 \pm 50 \\
\text { AD } 750 \\
\delta^{13} C=-29.5 \%
\end{gathered}
$$

Heavily darkened wood from sternless monoxilous Pirogue 2 (Find A), $15.9 \mathrm{~m}$ long, max diam ca $1.1 \mathrm{~m}$, cut out of oak trunk, estimated ca 25 to $30 \mathrm{~m}$ long. Pirogue, probably longest in Europe, rested inclined and partly buried in river bed near left bank, parallel to current. Comment: see R-917 $\alpha$.

\section{R-919 $\alpha$. Selvazzano C}

$$
\begin{array}{r}
1020 \pm 50 \\
\text { AD } 930 \\
\delta^{1 s} C=-28.0 \%
\end{array}
$$

Heavily darkened wood (Find C) from monoxilous fragment, ca $7 \mathrm{~m}$ long and $0.8 \mathrm{~m}$ wide, of unknown use, with 2 opposite groups of 4 holes, found on river bottom near pirogues. Comment: see R-917 $\alpha$. 


\section{R-920 $\alpha$. Selvazzano D}

Heavily darkened wood (Find D) presumably fragment of pirogue resting on river bottom near A/C finds. Comment: see R-917 $\alpha$.

General Comment: in river near pirogues bronze objects and pottery of various periods (prehistoric, Roman, medieval, modern) were found. From technical and phytogeog data, pirogues were believed of prehistoric age. ${ }^{14} \mathrm{C}$ date attribute them to Middle ages.

\section{R-894 $\alpha$. Laghi di Monticolo, pirogue}

$$
\begin{aligned}
& \mathbf{7 1 0} \pm \mathbf{5 0} \\
& \text { AD 1240 } \\
& \delta^{1 s} C=-28.8^{\%} \%
\end{aligned}
$$

Darkened wood, fragment from monoxilous pirogue cut out of trunk, $3.4 \mathrm{~m}$ long and $70 \mathrm{~cm}$ wide, found almost entire half buried in bottom silty sediments, $8 \mathrm{~m}$ water depth, ca $30 \mathrm{~m}$ from $\mathrm{W}$ shore in larger of 2 small Monticolo Lakes, Comm Appiano, prov Bolzano, Alto Adige $\left(46^{\circ}\right.$ $\left.25^{\prime} 18^{\prime \prime} \mathrm{N}, 11^{\circ} 17^{\prime} 57^{\prime \prime} \mathrm{E}\right)$ at $+490 \mathrm{~m}$. Pirogue, discovered on $26 \mathrm{Sept}$ 1971 by skin-diver Roversi and recovered by Gruppo Sommozzatori Bolzano under direction of $\mathrm{H}$ Schwarzer, is temporarily kept in storage at Mus Civico, Bolzano. Subm 1971 by Mus Tridentino Sci Naturali, Trento. Comment: pirogue, along with remains of 2 more pirogues also found half buried in bottom in same area of large Monticolo L, was considered, though doubtfully, of Prehistoric age (Lunz, 1973) because of its way of manufacture and assoc with other finds of prehistoric perilacustrine settlements in the area, probably of Bronze age. ${ }^{14} \mathrm{C}$ date refutes attribution. See also Selvazzano pirogue series, above.

\section{R-1001. Buco della Sabbia, Civate \\ $3680 \pm 110$ \\ $1730 \mathrm{BC}$ \\ $\delta^{13} C=-24.6 \%$}

Collagen of human bones from inhumation burials in inner Chamber C of Buco della Sabbia, a small karst cave on slope of Cornizzolo Mt at Linate, PreAlps of Lombardy, Comm Civate, prov Como $\left(45^{\circ} 49^{\prime}\right.$ $\left.41^{\prime \prime} \mathrm{N}, 9^{\circ} 19^{\prime} 38^{\prime \prime} \mathrm{E}\right)$ at $+445 \mathrm{~m}$. Coll 1964 and subm 1971 by O Cornaggia Castiglioni who excavated for Sopr Antichità Lombardia, Milan. Comment: in Buco della Sabbia necropolis new Eneolithic archaic facies in Lombardy named Civate culture was id and dated 2300 to 2500 BC, as judged immediately subsequent Upper Neolithic Lagozza culture, dated 3000 to 2700 BC, see: Pi-34 (R, 1961, v 3, p 102) and R-338, -337 (R, 1968, v 10, p 356-357) (Cornaggia Castiglioni, 1971; Cornaggia Castiglioni \& De Michele, 1963; Corrain \& Cornaggia Castiglioni, 1964). R-1001 date strongly and inexplicably disagrees with expected age.

\section{R-1005. Grotta della Ferrovia}

$$
\begin{gathered}
11,700 \pm 200 \\
9750 \text { BC } \\
\delta^{1 s} C=-25.1 \% 0
\end{gathered}
$$

Charcoal from inner chamber, Sqs T, U, V, Cuts 2 to 4, of Ferrovia or Abbondanza cave deposit, right side of "Gola della Rossa" along 
Esino R upstream from Serra S Quirico, prov Ancona, Marche $\left(43^{\circ} 25^{\prime}\right.$ $\left.35^{\prime \prime} \mathrm{N}, 13^{\circ} 00^{\prime} 10^{\prime \prime} \mathrm{E}\right)$. Coll 1972 and subm 1973 by $\mathrm{G}$ Bartolomei and A. Broglio, both of Ist Geol, Paleont \& Paleont Umana, Univ Ferrara. Excavated in 1966, 1969, and 1972 with D Lollini, Sopr Antichità Marche. Deposit comprises Upper Paleolithic cultural horizon with flint industry of Evolute Epigravettian type, scarce remains of large unidentifiable mammals and abundant micromammals of numerous species, recovered by wet sieving (3mm mesh). Comment: diagram of micro-mammal assocs throughout deposit gives 1st detailed paleoclimatic sequence of Late Würm in central Italy (Bartolomei, 1966). ${ }^{14} \mathrm{C}$ age agrees both with industry and climatic sequence.

\section{Cava Due Madonne series}

Sec, $18 \mathrm{~m}$ high, in Due Madonne gravel quarry on Due Madonne Rd ca $380 \mathrm{~m}$ from junction of $106.7 \mathrm{~km}$ Via Emilia, SE suburbs of Bologna, Emilia (44 $\left.28^{\prime} 55^{\prime \prime} \mathrm{N}, 11^{\circ} 23^{\prime} 32^{\prime \prime} \mathrm{E}\right)$ at $+57 \mathrm{~m}$ exposed along $2 \mathrm{~km}$ Z-shaped perimeter from surface soil. At present sec is no longer exposed, quarry was infilled with waste materials ( $\mathrm{G}$ Bardella, written commun).

\section{R-720. Cava Due Madonne I}

$4640 \pm 50$

$2690 \mathrm{BC}$

$\delta^{19} C=-24.8 \%$

Charcoal embedded in probable stone floor of prehistoric dwelling in archaeol horizon, 1.60 to $1.90 \mathrm{~m}$, SW sec of quarry $\left(44^{\circ} 28^{\prime} 50^{\prime \prime} \mathrm{N}\right.$, $\left.11^{\circ} 23^{\prime} 30.5^{\prime \prime} \mathrm{E}\right)$. Coll and subm 1970 by G Bardella, Unione Speleologica Bolognese. Comment: a suitable cavity dug in sec showed remains of semicircular stone floor, diam $1.20 \mathrm{~m}$, made by upper layer of large stone pebbles, partly reddened by fire, resting on lower sandstone bits. Finds of phthanite implements and pottery attributable to Early Eneolithic were comparable to cultural complexes in neighboring settlements (Malavolti, 1948; Scarani, 1963; Bardella, written commun). ${ }^{14} \mathrm{C}$ date agrees.

\section{R-719A $\alpha$. Cava Due Madonne II}

\section{R-719B $\alpha$. Cava Due Madonne II}

$$
\begin{array}{r}
>\mathbf{4 2 , 0 0 0} \\
\delta^{1 s} C=-26.3 \% \\
>\mathbf{4 2 , 0 0 0} \\
\delta^{1 s} C=-26.0 \%
\end{array}
$$

Heavily darkened apparently lignitous wood flattened fragment found in stratified fluvial sand, 3.10 to $3.30 \mathrm{~m}$ at top of pebbly-gravelly alluvial cone, SE sec of quarry $\left(44^{\circ} 28^{\prime} 58^{\prime \prime} \mathrm{N}, 11^{\circ} 23^{\prime} 33^{\prime \prime} \mathrm{E}\right)$. Coll and subm 1969 by G Bardella. Comment: sample pretreated with $5 \% \mathrm{HCl}$ : no carbonates or $\mathrm{Fe}^{++}$and $\mathrm{Fe}^{+++}$present; additional leaching with $.2 \mathrm{~N}$ $\mathrm{NaOH}$ reveals scarce humic fraction. R-920A $\alpha$ from dark compact inner part; R-720B $\alpha$ small wood polyedra easily detached from both sides of outer part showing regular polygonal fissures 0.5 to $0.8 \mathrm{~cm}$ deep. Geopaleontol data, ie, ${ }^{14} \mathrm{C}$ minimum age of wood at top and reworked phthanite implements in upper part of gravel belonging to Lower and Middle Paleolithic cultures, from Clactonian up to proto-Levalloisian 
and Levalloisian, attributes Würm I/Würm II interstadial age to last phase of alluvial cone formation ( $G$ Bardella, written commun).

\section{R-978. Poggio Pietricci Etruscan Tombs}

$2250 \pm 50$

$300 \mathrm{BC}$

$\delta^{13} \mathrm{C}=-23.5 \%$

Collagen of bones of 6 human bodies from Tombs 1, 2, 4, 6, \& 7 of Poggio Pietricci necropolis overhanging Radicata torrent, E facing Cutignolo small lake, Comm Marsiliana, prov Grosseto, Tuscany $\left(42^{\circ} 30^{\prime} 16^{\prime \prime}\right.$ $\mathrm{N}, 11^{\circ} 20^{\prime} 41^{\prime \prime}$ E) at $+165 \mathrm{~m}$. Excavations by A Mazzolai, Mus Archeol Maremma, Grosseto, for Sopr Antichità Etruria, revealed 16 Etruscan rock tombs of "Cavernelle circolari with dromos" type, containing scarce bone remains and a few funerary objects. Tombs had been plundered in both Roman and modern times. Bone remains, housed in Maremma Mus, coll 1969 by A Mazzolai and subm 1972 by the late M Franceschini, Ist Anat Umana Norm, Univ Rome. Comment: funerary objects, mainly pottery and bucchero, from Tomb 11 only dated 1st quarter of 6th century BC (Mondello et al, 1977). MASCA corrected date, 430 to $390 \mathrm{BC}$, though rough average age for Tombs 1, 2, 4, 6, \& 7 , agrees well with archaeol age of Tomb 11, also assuming a short-life necropolis.

\section{Argentario shipwreck series}

Two fragments of very impaired wood from different shipwrecks recovered by Bathyscaphe P-82, Sub Sea Oil Services, Milan, in Tyrrenian Sea off the shore of Argentario Mt, water depth $42 \mathrm{~m}\left(42^{\circ} 19^{\prime} 13^{\prime \prime} \mathrm{N}, 11^{\circ}\right.$ $26^{\prime} 04^{\prime \prime}$ E). Subm 1974 by F Gnetti, SSOS.

\section{R-1080 $\alpha$. Argentario Wreck 1}

Fragment of darkened and very impaired wood from Wreck 1.

\section{R-1081 $\alpha$. Argentario Wreck 2}

Fragment of darkened and very impaired wood from Wreck 2.

General Comment: according to ${ }^{14} \mathrm{C}$ ages, shipwrecks not old enough to be worth recovering, as was thought.

\section{Palidoro series}

In 1954 A C Blanc uncovered a prehistoric settlement found during mining in travertine formation at Palidoro, via Aurelia ca $30 \mathrm{~km} \mathrm{~W}$ Rome, Latium ( $41^{\circ} 56^{\prime} 09^{\prime \prime} \mathrm{N}, 12^{\circ} 11^{\prime} 32^{\prime \prime} \mathrm{E}$ ) at ca $+40 \mathrm{~m}$ (Blanc, 1955). Excavated 1955 by P F Cassoli, and 1956 and 1959 by V G Chiappella (1956, 1958-61), both of Ist Italiano Paleont Umana. Upper levels of $\mathrm{N}$ edge of a relict spur in travertine quarry, ca $2 \mathrm{~m}$ thick, contained bones of domestic animals and potsherds of Middle ages, Roman period, Iron and Bronze ages, and Middle Neolithic. Lower cultural level contained 
many bones and bone fragments, some charred, mainly Cervus, Equus caballus, and Equus hydruntinus, some Capreolus and Sus scrofa, and scarce birds (Cassoli, 1976). Also present were many flint tools of Upper Paleolithic industry, Evolute Epigravettian type: mainly burins, mostly dihedral and on fracture, end-scrapers, mostly on blade, various backed microliths and several truncated and notched bladelets, and very abundant unretouched blades on flakes and rejects (Bietti, 1976). Bone-breccia probably part of deposit in small cave or shelter half-way up travertine cliff formed by Rio Palidoro or "Fosso della Caduta" in S side of travertine formation and crumbled before Neolithic time. Bones and charred bones, Bos and Equus, from travertine bone-breccia coll 1955 by P F Cassoli and 1956, 1959 by V G Chiappella; subm 1972, 1974 by A Bietti, Ist It Paleont Umana.

1955 excavations-Trench $\mathrm{B}, 80 \mathrm{~cm}$ deep, dug throughout breccia with Evolute Epigravettian industry comprising from top, Cuts 1 to $8,10 \mathrm{~cm}$ thick.

\section{R-944. Palidoro Tl I}

Collagen of animal bones from Cut 1 .

\section{R-944a. Palidoro Tl 1}

Charred animal bones from Cut 1.

\section{R-1066. Palidoro TI 2}

Collagen of animal bones from Cut 2 .

\section{R-1067. Palidoro Tl 3}

Collagen of animal bones from Cut 3 .

\section{R-945. Palidoro Tl 4}

Collagen of animal bones from Cut 4 .

R-946. Palidoro Tl 5

Collagen of animal bones from Cut 5 .

\section{R-947. Palidoro Tl 6}

Collagen of animal bones from Cut 6 .
$14,580 \pm 130$

$12,630 \mathrm{BC}$

$\delta^{13} C=-23.5 \%$

$13,950 \pm 100$

12,000 вC

$\delta^{13} C=-21.6 \%$

$14,780 \pm 130$

$12,830 \mathrm{BC}$

$\delta^{13} C=-23.9 \%$

$15,190 \pm 120$

13,240 BC

$\delta^{13} \mathrm{C}=-23.7 \%$

$15,310 \pm 160$

$13,360 \mathrm{BC}$

$\delta^{13} C=-24.3 \%$

$15,340 \pm 140$

13,390 BC

$\delta^{13} C=-23.8 \%$

$15,660 \pm 130$

13,710 вс

$\delta^{13} C=-23.6 \%$ 


\section{R-948. Palidoro Tl 7}

Collagen of animal bones from Cut 7.

\section{R-949. Palidoro Tl 8}

Collagen of animal bones from Cut 8 .
$15,900 \pm 150$

13,950 BC

$\delta^{13} C=-24.5 \%$

$15,520 \pm 140$

13,570 BC

$\delta^{13} C=-24.7 \%$

1956 and 1959 excavations_-Trench Gi, > 3m deep, E side of Trench B, dug throughout upper and lower cultural levels; lower sec in breccia with Evolute Epigravettian industry comprises from top to sterile layer, Cuts 22 to 41 .

\section{R-1068. Palidoro Tl 25}

Collagen of animal bones from Cut 25.

\section{R-83. Palidoro Tl 25-30}

Charred animal bones presumably from Cuts 25 to 30. Comment: sample remeasured, see R-83 (R, 1964, v 6, p 79).

\section{R-1072. Palidoro TI 30}

Collagen of animal bones from Cut 30.

\section{R-950. Palidoro Tl 29.34}

Collagen of animal bones from Cuts 29 to 34 .

\section{R-968. Palidoro Tl $35-37$}

Collagen of animal bones from Cuts 35 to 37 .

\section{R-1069. Palidoro Tl 36, 39, 41}

Collagen of animal bones from Cuts 36, 39, and 41 .

\section{R-969. Palidoro TI 38-41}

Charred animal bones from Cuts 38 to 41 .
$14,330 \pm 340$ $12,380 \mathrm{BC}$ $\delta^{13} C=-24.5 \%$

$14,480 \pm 100$ $15,530 \mathrm{BC}$ $\delta^{13} \mathrm{C}=-21.9 \%$ $15,290 \pm 300$ 13,340 BC $\delta^{13} C=-23.7 \%$

$15,380 \pm 140$ 13,430 вс $\delta^{13} C=-21.8 \%$

$14,780 \pm 130$ $12,830 \mathrm{BC}$ $\delta^{13} \mathrm{C}=-21.9 \%$

$15,750 \pm 120$ $13,800 \mathrm{BC}$ $\delta^{13} C=-24.3 \%$

$15,970 \pm 110$ 14,020 вС $\delta^{13} \mathrm{C}=-23.1 \%$

General Comment: only bits of compact bone tissue, less liable to contamination, were used for dating purposes. Dates range almost continuously from ca 14,000 to $16,000 \mathrm{BP}$, agreeing with stratigraphy. However, for 1955 excavations, coincidence is observed within $2 \sigma$ of Cuts 4 
to 8 dates. Industry was classified by G Laplace (1964a, 1966) as Evolved Tardigravettian (Epigravettian) and as a typical example of internal evolution of industrial assemblage (Laplace, 1966, p 129-132). Cut 5 plays an intermediate role between lower level (Cuts 8 to 6) and a higher horizon (Cuts 4 to 1). A recent analysis of the same industry (Bietti, 1976) assigns it to a single Evolute Epigravettian horizon. ${ }^{14} \mathrm{C}$ dates obviously agree with both interpretations, but they do not confirm an intermediate role for Cut 5 industry. ${ }^{14} \mathrm{C}$ dates of 1966 and 1959 excavations substantially agree with those of 1955 .

\section{Colosseo series}

During restoration work in the Colosseum in 1973 a deposit was discovered obstructing entrance and along ca $80 \mathrm{~m}$ of $\mathrm{W}$ radial drain tunnel of original water supply and sewer system. Archaeol excavations made by G Carettoni and C Moccheggiani Carpano, both of Sopr Antichità Roma, with Servizio Sci Sussidiarie Archeol C N R. Along $20 \mathrm{~cm}$ of $\mathrm{W}$ tunnel, up to $30 \mathrm{~cm}$ from vault, was a silty-clayey deposit, caused by stagnation and decantation of alluvial water in 2 nd half of 6 th century $\mathrm{AD}$, when tunnel, $1.30 \mathrm{~m}$ wide and $1.80 \mathrm{~m}$ high, was almost out of use owing to previous crumble. Deposit kept intact in lower part in contact with floor, an archaeol layer, ca $30 \mathrm{~cm}$ thick, sealed by upper sterile layer, consisting of all kinds of waste materials, ie, vegetal, animal, and cultural remains from inside the amphitheatre and its surrounding areas. Various studies on these finds are still in progress and are providing invaluable archaeol documentation of 4 th century Colosseum (Picozzi, 1974; Ferri-Ricchi, 1974; Corona, 1974a). Wood plank, pile, and peachpits coll and subm by C Moccheggiani Carpano.

\section{R-953 $\alpha$. Colosseo 1}

$$
\begin{gathered}
\mathbf{1 9 3 0} \pm \mathbf{5 0} \\
\text { AD 20 } \\
\delta^{1 s} \mathrm{C}=-26.4 \% \text { o }
\end{gathered}
$$

Wood (Quercus sp deciduous group, probably Quercus pubescens Wild) id by E Corona, fragment of plank, $80 \times 16 \mathrm{~cm}, 3 \mathrm{~cm}$ thick, found in situ, after removing deposit, inside $\mathrm{W}$ radial drain tunnel between bipedal brick floor and left wall at ca $10 \mathrm{~m}$ from entrance. Comment: plank is from wooden form board of trass-mortar casting used to construct tunnel along with foundation. ${ }^{14} \mathrm{C}$ date and MASCA corrected one, AD 20-40 to 110-130, agree with dendrochronologic age of plank from trunk ca 100 yr old felled between AD 73 and 84 (Corona, 1974a) and provide archaeol evidence of Colosseum construction date, AD 70 to 80 .

R-1002 $\alpha$. Colosseo 3

$1770 \pm 50$

$$
\text { AD } 180
$$

$$
\delta^{13} C=-27.1 \%
$$

R-1002 $\alpha_{1}$. Colosseo 3

$$
1820 \pm 50
$$

\section{AD 130}

$\delta^{13} C=-27.6 \%$

Badly damaged wood (Quercus sp deciduous group, probably Quer- 
cus pubescens Wild) id by E Corona, upper part, ca $30 \mathrm{~cm}$ long, of a timber, $40 \times 20 \mathrm{~cm}$ wide and presumably several $\mathrm{m}$ long, found in situ, after removing deposit, inside $W$ radial drain tunnel vertically protruding from bipedal brick floor and adhering to right concrete wall at ca $13 \mathrm{~m}$ from entrance. Comment: R-1002 $\alpha_{1}$ was remeasured after repeated leaching with $.2 \mathrm{~N} \mathrm{NaOH}$. According to archaeol data, timber is considered integral part of form board. MASCA corrected date, AD 35-120 to 115-180 agrees.

\section{R-983 $\alpha$. Colosseo 2}

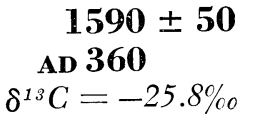

Well preserved peach-pits (Prunus persica Batsch) id by M Follieri, Ist Bot, Univ Rome, from archaeol basal layer sealed by overlying sterile sediment of $\mathrm{W}$ radial drain tunnel. Comment: ${ }^{14} \mathrm{C}$ date and MASCA corrected one, AD 320-350 to 440 agree with age, 2nd half of 4 th century AD, attributed archaeologically and historically to all waste materials of deposit.

\section{R-858. Foro Romano, Basilica Emilia}

\section{R-858 $\alpha$. Foro Romano, Basilica Emilia}

$1900 \pm 50$

AD 50

$$
\delta^{13} C=-26.2 \%
$$

Well preserved wood (Albies alba Mill) id by E Corona, fragment of trunk, diam $20 \mathrm{~cm}$ and $\mathrm{ca} 45 \mathrm{~cm}$ long, at $3 \mathrm{~m}$ depth under floor of Taberna X, Basilica Emilia, Roman Forum. Coll and subm 1971 by $\mathrm{H}$ Bauer. Comment: R-858 is inner part and R-858a is outer part of trunk; test with $.2 \mathrm{~N} \mathrm{NaOH}$ did not disclose humic material. 135 tree rings were id; tentative dendrochronology by $\mathrm{E}$ Corona dates felling after $39 \mathrm{BC}$ or AD 30 (Corona, 1974b). Trunk left its mark in trass-cement mortar foundation of wall protruding from floor of Taberna $\mathrm{X}$, made of yellow and red tuff blocks. Use of yellow tuff and other archaeol data id protruding wall as part of older series of narrower tabernae dated $78-60$ or $55-34$ BC. ${ }^{14} \mathrm{C}$ date agrees but excludes its attribution to 1st oldest tabernae of Basilica, also built with yellow tuff, mentioned in $179 \mathrm{BC}$ (Bauer, written commun). Former ${ }^{14} \mathrm{C}$ date for Basilica Emilia: R-17, $2120 \pm 190$ (R, 1964, v 6, p 83).

\section{R-1007. Roma, Sette Sale}

$940 \pm 50$

\section{AD 1010}

$\delta^{13} C=-23.2 \%$

Collagen from bones of human bodies buried in Room IX of Sette Sale, Colle Oppio, Rome, discovered during archaeol excavations carried out 1966-67 by X Ripartizione, Comune di Roma; coll and subm 1968. Sette Sale is Roman bldg consisting of 9 large rooms built AD 104 as water reservoir supplying nearby Terme di Traiano, presently in a Comm 
archaeol area bounded by Via delle Terme di Traiano, Via Mecenate, and Brancaccio property. In Room IX, 5.30m wide $\times 15 \mathrm{~m}$ long, a cemetery was discovered, where many adult bodies without any funerary furniture were buried close to each other in upper part of earthy deposit, $>1 \mathrm{~m}$ thick, surface covering approx half the room. Many minute inscriptions, still undeciphered, are engraved on walls (Cozza, 1975). Comment: historic or archaeol data on Sette Sale as a burial place are still unknown.

\section{Roma, Battistero Lateranense series}

Wood from framework of Battistero Lateranense, Rome, coll 19661967 by G B Pelliccioni, during restoration and archaeol studies in Battistero Lateranense site, dir by Pontificia Com per la Tutela dei Monumenti, and subm by V Federici, Gabinetto Ricerche Mus Vaticani, Rome (Pelliccioni, 1973).

\section{R-381. Battistero Lateranense 1}

Well preserved wood from wooden platband in situ in upper part of one of a series of holes, ca $40 \times 40 \mathrm{~cm}$ and $35 \mathrm{~cm}$ deep, for wooden beams supporting ceiling in longest wall of large room, $24 \times 11 \mathrm{~m}$, before construction of Battistero, partly overlaying it at ca $1.60 \mathrm{~m}$ above floor. Holes in wall are now at height of ca $6.65 \mathrm{~m}$ above present Battistero floor. Comment: architecturally, wall should date 2nd half of 3rd century AD; ${ }^{14} \mathrm{G}$ date agrees and MASCA corrected one remains unchanged, AD 160 to 260 .

\section{R-382. Battistero Lateranense 2}

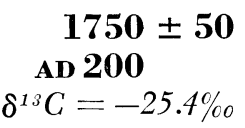

Well preserved wood from original platband in situ of a window in S Giovanni Evangelista Chapel. Construction historically ascribed to Pope Ilario, AD 461-468. Window is older than cross-vault with mosaic in Ghapel which may have been built between Hilary's pontificate and 8th century AD. Comment: ${ }^{14} \mathrm{C}$ date shows re-utilization of wood, at least 2 centuries old, for platband.

\section{R-384 $\alpha$. Battistero Lateranense 4}

$$
\begin{array}{r}
\mathbf{2 8 0} \pm \mathbf{5 0} \\
\text { AD } 1670 \\
\delta^{13} C=-25.5 \%
\end{array}
$$

Wood from large square timber, $30 \mathrm{~cm}^{2}$, vertically in foundation wall of left apse in atrium of Battistero, possibly built in 4th or 5 th century AD. Comment: dates timber to late restoration of foundation or, perhaps, to reconstruction of apse, sponsored by Lercari family. MASCA corrected date: AD 1520 to 1640 .

General Comment: other wood from Battistero previously dated (R, 1967, v $9, \mathrm{p} 353-354)$. 


\section{R-1021 $\alpha$. Tevere wreck}

Wooden (Conifera) swan-neck-shaped object with metal ornaments from Tiber R bed, near Rome. Subm 1974 by W Ventrella, Roma. Comment: impossible to determine age of find on stylistic grounds; probably an "aplustre" fragment (ornament of ship stern). ${ }^{14} \mathrm{C}$ date is from Roman Imperial period.

\section{R-681. Peschio Ranaro}

$$
\begin{aligned}
& 9730 \pm 150 \\
& 7780 \mathrm{BC}
\end{aligned}
$$$$
\delta^{13} \mathrm{C}=-22.5 \%
$$

In 1966, I Biddittu discovered prehistoric settlement, Peschio Ranaro, a Karst cave in Mesozoic limestone on slope of Ernici Mts, ca $1 \mathrm{~km} \mathrm{NNE}$ Comm Collepardo, on rd to Abbazia di Trisulti, prov Frosinone, Latium $\left(41^{\circ} 46^{\prime} 14^{\prime \prime} \mathrm{N}, 13^{\circ} 22^{\prime} 38^{\prime \prime} \mathrm{E}\right)$ at ca $+700 \mathrm{~m}$ (Biddittu, 1967-68). Remains of sediment with fauna, industry and pottery still adhering to cave walls indicate layer, ca $1.10 \mathrm{~m}$ thick, removed possibly recently from upper part of deposit, probably to use cave as a stable. In 1969, a trench, dug in remaining deposit by the late $\mathrm{L}$ Cardini and I Biddittu, both of Ist Italiano Paleont Umana, revealed from upper horizon, ca $1 \mathrm{~m}$ thick, plentiful Upper Paleolithic microlithic flint industry of final Epigravettian type according to $\mathrm{G}$ Laplace (1964a, b) characterized by scarce simple and break burins, numerous short and circular end-scrapers, backed and truncated bladelets, backed points, geometric and denticulated. Faunal remains included Capra ibex, frequent Cervus elaphus, Marmota Marmota, Mustela nivalis, Talpa coeca. Lower horizon, $40 \mathrm{~cm}$ thick, revealed scarce fauna similar to those above and flint industry too scarce to be id. From industrial and faunal remains, "Peschio Ranaro" was id as seasonal hunting settlement (Cardini, 1969; Biddittu, 1973). Charred bones from upper Paleolithic horizon coll and subm by L Cardini and I Biddittu. Comment: ${ }^{14} \mathrm{C}$ date agrees with final Epigravettian in Italy and can be compared with Grotta della Madonna Layer X, Secs 48-50 and 54-55 ages, from 9020 to 10,450 (R, 1967, v 9, p 355-356).

\section{Riparo $C$ delle Grotte Cipolliane series}

Charred bones from cuts of Layer 3 of Cipolliane Caves C shelter in Tertiary limestone cliff along Ionian coast ca $2 \mathrm{~km} \mathrm{~S}$ Marina di Novaglie, prov Lecce, Apulia $\left(39^{\circ} 51^{\prime} 10^{\prime \prime} \mathrm{N}, 18^{\circ} 23^{\prime} 25^{\prime \prime} \mathrm{E}\right)$ at $+30 \mathrm{~m}$. Coll 1964 and subm 1966 by A Palma di Cesnola, Ist Antropol, Univ Siena. Deposit comprises 4 layers with Upper Paleolithic cultural horizons; Layer 3 includes transition from Evolute to Late Epigravettian with flint industry mainly of backed blades, backed and truncated blades, burins and short end-scrapers. Typologically analyzed by Laplace method (Laplace, 1964b, 1966, 1968). Fauna includes frequent Bos Caballus and Cervus, scarce micromammals and birds (Palma di Cesnola, 1962, 1967; Palma di Cesnola and Borzatti, 1962; Gambassini, 1970). 


\section{R-353. Cipolliane C3, I-II}

Charred bones from Cuts I and II, top of Layer 3.

\section{R-355. Cipolliane C3, III}

Charred bones from Cut III, middle of Layer 3.

\section{R-356. Cipolliane C3, VI-VII}

Charred bones from Cuts VI and VII, bottom of Layer 3 . direct comparison, but some refs are possible to Epigravettian industries like Ugento, Apulia: R-271, 14,170 \pm 170 and R-272, 13,870 \pm 110 (R, 1967, v 9, p 359); Palidoro, Latium (see Palidoro series, above); Riparo Tagliente, Veneto, R-604, 12,000 \pm 400, and R-605, 13,330 \pm 160 (R, 1970 , v 12, p 600).

\section{R-346. Passo di Corvo}

Charred vegetable remains, mainly wheat and other cereals, caryopses and leguminous seeds, id 1973 by M Follieri. From 4m depth to base, at $6.50 \mathrm{~m}$, in earth filling of pit at NE C-shaped ditch or "compound" excavated in Area A, Passo di Corvo Neolithic ditched village, $8 \mathrm{~km}$ NE Foggia, Tavoliere della Puglia $\left(41^{\circ} 33^{\prime} 10^{\prime \prime} \mathrm{N}, 15^{\circ} 35^{\prime} 18^{\prime \prime} \mathrm{E}\right)$ at $+70 \mathrm{~m}$. Coill 1969 and subm 1971 by S Tiné, Ist Archeol, Univ Genova, who has been excavating since 1965 (Tiné, 1968, 1972, 1975a, b). Passo di Corvo is largest of $>1000$ Neolithic ditched villages id by aerial photograph, scattered mainly in Apulia Tavoliere (Bradford, 1957) characterized by many typical inner $\mathrm{C}$ ditches (compounds) and outer circular, concentric ditches, the latter enclosing villages, the function of which is not yet known (Tiné, 1975a, b). Comment: in pit, both "figulina" bichrome pottery with unedged-red-band painted decoration and black planed ware of IVa cultural phase, "Passo di Corvo style", of Tavoliere Neolithic were assoc. ${ }^{14} \mathrm{C}$ date agrees well with expected age for IVa phase, placing it between available dates for preceding III phase, "Masseria della Quercia style": R-350, $5050 \pm 100$ BC and R-351, $4590 \pm 65$ BC and for subsequent IVb phase "Scaloria bassa style": R-349, $3530 \pm 70$ BC (R, 1969, v 11, p 485-486) of Tavoliere Neolithic cultures. Date also agrees with similar pottery at Villaggio Leopardi, Pescara, Pi-101, $4630 \pm 135$ and at Grotta dei Piccioni, Pescara, Pi-46, $4300 \pm 130$ BG (R, 1961, v 3, p 100).

\section{R.910. Santuario dell'Incoronata, statue}

$600 \pm 50$

AD 1350

$\delta^{13} C=-25.0 \%$ 


\section{R-910A. Santuario dell'Incoronata, statue}

Well preserved wood (Juglans regia) from fragment chiselled out of an original part of painted wooden statue of Maria SS Incoronata, worshipped for many centuries in old Sanctuary of Incoronata, $13 \mathrm{~km} \mathrm{SE}$ Foggia, Tavoliere plain, at junction of State Rd 16 at Km 11.3, Apulia. Coll 1970 and subm 1973 by Father G D'Onorio De Meo F D P and G Moro, Ist Centrale del Restauro, Roma. Comment: R-910 pretreated with 5\% HCl. Stylistic and chemical analyses suggest late Medieval age, AD 1280-1320, in agreement with ${ }^{14} \mathrm{C}$ date (D'Onorio De Meo, 1975). MASCA corrected dates: R-910, AD 1305 to 1380; R-910A, AD 1260 to 1350.

\section{B. Sardinia}

\section{R-963 $\alpha$. Sa Turricula}

$$
\begin{gathered}
3460 \pm 50 \\
1510 \text { BC } \\
\delta^{13} C=-24.5 \%
\end{gathered}
$$

Charcoal from hearth of Hut 1, Layer 2, Bonnanaro culture, of prehistoric village at Sa Turricula, ca $1 \mathrm{~km}$ ENE Comm Muros, prov Sassari $\left(40^{\circ} 42^{\prime} 27^{\prime \prime} \mathrm{N}, 8^{\circ} 36^{\prime} 48^{\prime \prime} \mathrm{E}\right)$ at $+392 \mathrm{~m}$. Coll 1972 and subm 1973 by M L Ferrarese Ceruti, Ist Antichità, Archeol e Arte, Univ Cagliari for Sopr Antichità Sassari. Comment: date agrees; Bonnanaro culture, Bronze age, until now only known from burials, probably follows Monte Claro culture: R-677, $3690 \pm 60(\mathrm{R}, 1970$, v 12, p 607) and Gsy-323, $3770 \pm 250(\mathrm{R}, 1966, \mathrm{v} 8, \mathrm{p} 86)$, and seems connected to 1st Nuragic manifestations: K-151, $3420 \pm 200(\mathrm{R}, 1960$, v 2, p 10) (Contu, 1972a; Ferrarese Ceruti, 1972).

\section{R-916. Su Crucifissu Mannu}

$$
\begin{array}{r}
\mathbf{7 9 0} \pm \mathbf{5 0} \\
\text { AD } 1160 \\
\delta^{13} C=-22.8 \%
\end{array}
$$

Charcoal scattered in Layer 2, main cell of Tomb XVI, in "domus de janas" hypogean necropolis, Su Crucifissu Mannu, in low limestone hill S Porto Torres, $\mathrm{Km} 4$ along State Rd 131, Prov Sassari (40 48 $38^{\prime \prime}$ N, $8^{\circ} 26^{\prime} 37^{\prime \prime}$ E) at $+75 \mathrm{~m}$. Coll and subm 1972 by M L Ferrarese Ceruti for Sopr Antichità Sassari. Comment: Layer 2 contains secondary burials of Bonnanaro culture (see Sa Turricula, above); disagreement of ${ }^{14} \mathrm{C}$ date attributed to mixing of more recent charcoal due to water percolating down hill and entering tomb through 2 fissures in upper edge of stone slab still closing entrance (Contu, 1972b; Ferrarese Ceruti, 1972).

\section{R-1060. Oridda}

$3170 \pm 50$

\section{$1220 \mathrm{BC}$}

$$
\delta^{13} C=-23.6 \%
$$

Collagen from human bones from Zone D, Layer II of archaeol deposit of hypogean tomb at Oridda, Comm Sennori, $9 \mathrm{~km}$ N Sassari $\left(40^{\circ} 47^{\prime} 23^{\prime \prime} \mathrm{N}, 8^{\circ} 35^{\prime} 33^{\prime \prime} \mathrm{E}\right)$ at $+230 \mathrm{~m}$. Coll and subm 1966 by E Castaldi, Ist Paletnol, Univ Rome, for Sopr Antichità Sassari. Comment: 
Oridda hypogeum, discovered in 1960, consists of a sepulchral chamber, $6.50 \mathrm{~m}$ long, 0.75 to $0.85 \mathrm{~m}$ wide and up to $1.65 \mathrm{~m}$ high, entirely excavated in weathered vulcanite, reinforced with small limestone blocks and covered with slabs, with open-air "porta-stele" and exedra. Zone D, Layer I and II, $65 \mathrm{~cm}$ thick, $4 \mathrm{~m}$ from chamber background, yielded abundant human bones and pottery attributable to Nuragic period (Contu, 1.966, Castaldi, 1969). Structurally, Oridda was classified as "Giant's tomb" A3 of mixed type (Castaldi, 1969, 1975) and, according to G Lilliu, Nuragic cultural sequence (Lilliu, 1963, 1967) attributed to Early Archaic Nuragic II, 12th to 10th centuries BC. Pottery complex agrees and ${ }^{14} \mathrm{C}$ date confirms attribution.

$$
\text { C. Sicily }
$$

\section{R.484. Grotta Giovanna}

$12,840 \pm 100$ 10,890 BC $\delta^{13} C=-22.7 \%$

Charred bones from upper Paleolithic cultural horizon of Grotta Giovanna, a small Karst cave at Contrada Spinagallo, $3.7 \mathrm{~km}$ along rd joining Km 11 of Prov Rd Siracusa-Canicattini to Cassibile, Prov Siracusa $\left(37^{\circ} 00^{\prime} 00^{\prime \prime} \mathrm{N}, 15^{\circ} 11^{\prime} 38^{\prime \prime} \mathrm{E}\right)$. Coll and subm 1968 by the late L Cardini and by S Pianese, Ist Italiano Paleont Umana, Rome. Deposit discovered 1965 (Bernabò Brea, 1965); excavations, made by Ist Italiano Paleont Umana with Sopr Antichità Sicilia Orientale, Siracusa, revealed from upper layer, ca $40 \mathrm{~cm}$ thick, undefinable pottery, Holocene fauna, mainly domestic animals, and abundant fresh water mollusk shells, and food refuse; Upper Paleolithic cultural horizon, ca $60 \mathrm{~cm}$ thick, yielded flint industry typologically analyzed according to Laplace (1964a, b) as final Epigravettian of Sicily; Pleistocene fauna, largely Bos primigenius, Equus hydruntinus, Cervus elaphus, and abundant microfauna. Ca 70 small limestone blocks, with linear engravings, one with engraving of an ox, are 1st evidence of Upper Paleolithic mobiliar art in Sicily. Lower layer, loessic red earth, over $2 \mathrm{~m}$ thick, with wild fauna, Hyaena, Elephas mnaidriensis, Hippopotamus sp, Cervus sp, and sterile of industry (Cardini, 1968-71; Pianese, 1968). Comment: ${ }^{14} \mathrm{C}$ date agrees with cultural horizon and can be compared in Sicily with: Grotta dell'Acqua Fitusa, Agrigento, F-26, 13,760 \pm 330 and with Grotta Perciata, Palermo, F-27, 11,960 $\pm 330(\mathrm{R}, 1973$, v 15, p 483).

\section{Turkey}

\section{Arslantepe (Malatya) series}

During past few yr Italian Archaeol Mission in Eastern Anatolia, Ist Paletnol, Univ Rome, Head, S M Puglisi, has been excavating in the hüyük of Arslantepe, $5 \mathrm{~km}$ NE Malatya, ca $0.5 \mathrm{~km} \mathrm{~N}$ Orduzu village, $\mathrm{E}$ Anatolia (38 $\left.22^{\prime} 08^{\prime \prime} \mathrm{N}, 38^{\circ} 23^{\prime} 38^{\prime \prime} \mathrm{E}\right)$ at $+912 \mathrm{~m}$. Arslantepe is a mound, $30 \mathrm{~m}$ high, max length $\mathrm{NE}$ to $\mathrm{SW}$ ca $250 \mathrm{~m}$, formed by accumulating remains of superimposed settlements, VII to I periods of Arslantepe cultural sequence: VII, Late Chalcolithic; VI, Early Bronze, various phases; V, 
Middle and Late Bronze, 2 phases; IV, recent Hittite-Imperial and IIIII, neo-Hittite levels; I Roman-Byzantine epoch; Islamic testimony. Until 1971, excavations were made in NE slopes of hüyük, where Delaporte uncovered Gate of the Lions of neo-Hittite age (Delaporte, 1940). This deposit is mainly formed by 5 superimposed town walls, gates, and bldgs of Hittite-Imperial and neo-Hittite periods; at base, Late Chalcolithic, Early Bronze final phase, Roman-Byzantine, and Islamic structures have been recognized. Since $1971 \mathrm{SW}$ slope is excavated. Almost whole deposit formed before end of Early Bronze but terraced structures of Middle Bronze, Hittite-Imperial and Roman age are also present; post-Roman cemetery dates end of hüyük life in area (Puglisi \&. Meriggi, 1964; Palmieri, 1969, 1970, 1973, 1974; Schneider Equini, 1970; Pecorella, 1975). 2 samples from Hittite levels already dated (R, 1966, v 8, p 405-406). Charred wood and charcoal of Late Chalcolithic and Bronze age, Periods VII, VI, and V, from both $\mathrm{NE}$ and $\mathrm{SW}$ excavation areas; coll and subm 1969 to 1973 by Alba Palmieri, Ist Italiano Paletnol, Univ Rome, who carried out excavations and archaeol studies.

VII Arslantepe period, Late Chalcolithic, NE area, 1970 and 1972

$$
\begin{array}{lll} 
& & 4860 \pm 50 \\
\text { R-931 } \alpha \text {. Arslantepe C3(E6) VIId A11 } & 2910 \mathrm{BC} \\
\delta^{18} C=-24.5 \%
\end{array}
$$

Charred wood on floor of Rm 11, Zone C3(E6), Level VIId. Coll 1970.

\section{R-932 $\alpha$. Arslantepe C3(E7) VIIe A21}

$4790 \pm 60$

2840 BC

$\delta^{13} \mathrm{C}=-23.9 \%$

Charcoal from filling of Rm 21, Zone C3(E7), Level VIIe. Coll 1972.

\section{R-933 $\alpha$. Arslantepe C3(E7) VIIe A21}

$4730 \pm 50$ 2780 BC

Charcoal from filling of Rm 21, Zone C3(E7), Level VIIe. Coll 1972. General Comment: dates refer to 2 rooms of Late Chalcolithic; cultural features similar to Amuq Phase F (Braidwood \& Braidwood, 1960) at sites in Keban Dam area, ie, Norşuntepe (Hauptmann, 1974) Tepecik (Esin, 1972) Korucu Tepe (Van Loon, 1973) and in Mesopotamia belonging to Late Uruk period (Porada, 1965). Pottery characterized by chaff-faced simple ware, chaff-faced red-slipped ware, and numerous bowls with bevelled inner rims, also present were obsidian triangular arrowheads and stamp seals. Dates of similar sites: Grai Resh, Singjar Dist, Iraq, P-468, $4939 \pm 75$ and P-469, $5169 \pm 64$ (R, 1963, v 5, p 85); Korucu Tepe, Altinova, E Elâzíg, Keban Dam area, Turkey, from 5400 to 5100 BP, GrN-5286-5287 (R, 1972, v 14, p 51) and P-1928, $5150 \pm 80$ (R, 1974, v 16, p 224) (Van Loon, 1973). 
VI Arslantepe period, Early Bronze, SW area, 1973

A. Old phase, Horizon 1 (Temple), Earlier Early Bronze I

R-1010. Arslantepe C8(2) A28

Charred grain from floor of $\mathrm{Rm} 28, \mathrm{Sq}$ C8(2).

R-1013. Arslantepe C8(9-10) A36 x9

Charcoal inside Pot 9 on floor of Rm 36, Balk C8(9-10).

R-1014. Arslantepe C8(9) A36

Charcoal from floor of Rm 36, Sq C8-9.

R-1015. Arslantepe C8(9-13) A36 x3

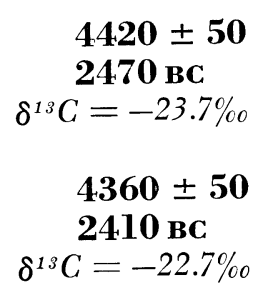
$G=-22.7 \%$

Charcoal inside Pot 3 on floor of Rm 36, Balk C8(9-13).

$$
\begin{array}{ccc} 
& & 3300 \pm 50 \\
\text { R-1016 } \alpha \text { Arslantepe C8(9-10) A36 x21 } & 1350 \mathrm{BC} \\
\delta^{1 s} C=-24.7 \%
\end{array}
$$$$
4270 \pm 50
$$$$
2320 \text { BC }
$$$$
\delta^{13} C=-24.2 \% \text { o }
$$$$
4310 \pm 50
$$$$
2360 \text { BC }
$$$$
\delta^{13} C=-25.7 \% \text { o }
$$

Charcoal inside Pot 21 on floor of Rm 36, Balk C8(9-10). Comment: aberrant date was rejected but no satisfactory explanation possible.

\section{R-1017. Arslantepe C8(10-11) A44}

R-1017 $\alpha$. Arslantepe C8(10-11) A44

$$
\begin{array}{rl}
\mathbf{4 3 6 0} \pm \mathbf{5 0} & \mathbf{2 4 1 0} \mathrm{BC} \\
\delta^{13} C=-23.3 \% \circ \\
\mathbf{4 3 6 0} \pm \mathbf{5 0} \\
\mathbf{2 4 1 0} \mathrm{BC} \\
\delta^{13} C=-23.1 \% \circ
\end{array}
$$

Charcoal on Bench 44 inside $\mathrm{Rm} 46$, Balk C8(10-11). Comment: sample leached with $.2 \mathrm{~N} \mathrm{NaOH}$.

R-1018. Arslantepe C8(10) A46

\section{R-1018 $\alpha$. Arslantepe C8(10) A46}

$$
\begin{aligned}
\mathbf{4 3 5 0} \pm \mathbf{5 0} \\
\mathbf{2 4 0 0} \mathrm{BC} \\
\delta^{13} C=-25.0 \% \text { } \\
\mathbf{4 4 1 0} \pm \mathbf{5 0} \\
\mathbf{2 4 6 0} \mathrm{BC} \\
\delta^{13} C=-24.3 \% \text { 。 }
\end{aligned}
$$

Charcoal from floor of $\mathrm{Rm} 46, \mathrm{Sq}$ C8-10. Comment: sample leached with .2N NaOH.

R-1019 $\alpha$. Arslantepe C8(10-14) A46

Charcoal from floor of Rm A46, Balk C8(10-14).

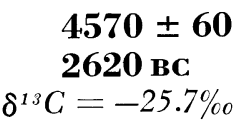


General Comment: dates refer to various rooms of a temple structure destroyed by fire. Archaeol finds, including: wheel-made pottery comprising reserved-slipware and hand-made red-black burnished pottery, "Cananean" lithic industry and a series of stamp-seal impressions, show affinities with both Amuq Phase G (Braidwood \& Braidwood, 1960) and Mesopotamian features of Jemdet Nasr-Early Dynastic I (Porada, 1965) as well as with Early Bronze I of Central Anatolia (Orthmann, 1963). Rather older date for Phase G at Tell Judiadah, Amuq, Turkey, P-1473, $4782 \pm 60(\mathrm{R}, 1973$, v 15, p 364).

B. Old phase, Horizon 2, Later Early Bronze I

\title{
R-1009. Arslantepe C8(11-15) A33
}

\author{
$4360 \pm 50$ \\ 2410 BC \\ $\delta^{13} C=-24.7 \%$ o
}

Charcoal from earth on floor of $\mathrm{Rm} 33$, Balk C8(11-15). Comment: dates room superimposed on temple structure destroyed by fire. Handmade red-black burnished pottery showing Transcaucasian Early Bronze affinities and subordinately wheel-made pottery comprising reserved-slip ware. Similar levels at Norsuntepe (Hauptmann, 1972) and at Taşkun Mevkii, both in Keban Dam area (Helms, 1973). Date can be compared with Early Transcaucasian II at Geoy Tepe K3: P-199, $4400 \pm 142$ (R, 1959, v 1, p 5) and at Yanik Tepe, ca 4500 to $4200 \mathrm{BP}, \mathrm{P}-1247-1250$ (R, 1969, v 11, p 151), both at Urmia Lake, Iran (Burney and Lang, 1971) and at Amiranis Gora, Georgia, TB-9, $4625 \pm 170$ (R, 1968, v 10, p 466) (Kushnareva and Chubinishvili, 1970).

C. Recent phase, Early Bronze BIII

R-1011. Arslantepe E8(13) A29

$3530 \pm 110$ $1580 \mathrm{BC}$

Charred grain from floor of Rm 29, Sq E8-13.

\section{R-1012. Arslantepe D8(12-16) A30}

$\mathbf{3 7 5 0} \pm \mathbf{5 0}$

$1800 \mathrm{BC}$

$\delta^{13} C=-25.4 \%$

R-1012 $\alpha$. Arslantepe D8(12-16) A30

$3840 \pm 110$

$1890 \mathrm{BC}$

$\delta^{13} C=-25.1 \%$ o

Charcoal from floor of $\mathrm{Rm}$ 30, Balk D8(12-16). Comment: sample leached with $.2 \mathrm{~N} \mathrm{NaOH}$.

\section{R-1008 $\alpha$. Arslantepe C7(16) A6}

$3800 \pm 50$

$1850 \mathrm{BC}$

Charcoal from hearth on floor of Rm 6, Sq C7-16. 
R-930 $\alpha$. Arslantepe D8(1) A2

$3680 \pm 50$

1730 BC

$\delta^{13} C=-24.9 \%$

Charcoal from floor of Rm 2, Sq D8-1. Comment: sample from 1971 excavations.

General Comment: ${ }^{14} \mathrm{C}$ dates refer to rooms of Early Bronze Final phase characterized in Malatya-Elâzig area by hand-made red-black burnished and bichrome and trichrome painted pottery. In Altinova, Keban Dam area, at Norşuntepe site, Horizon VI, a palatial citadel represents outstanding settlement for this period (Hauptmann, 1972). Dates for preceding Early Bronze II at Korucu Tepe from 4400 to 3800 вP: P-1617/18 -1628/29 (R, 1971, v 13, p 369); P-1926/27 (R, 1974, v 16, p 223); M-2376 ( $R$, 1972, v 14, p 219); GrN-6056, $4160 \pm 60$ (Van Loon, 1973). Moreover dates available for Early Transcaucasian III level at Yanik Tepe, Urmia Lake, Iran: P-1251/52 (R, 1969, v 11, p 151) and at Shengavit, Armenia, L.E-458, $4020 \pm 80$ (Kushnareva and Chubinishvili, 1970).

$V$ Arslantepe period, Old phase, Middle Bronze, $S W$ area, 1972

\section{R-926 $\alpha$. Arslantepe D8(8) A58}

Charred grain from floor of $\mathrm{Rm} 58$ with double hearth, Sq D8-8.

\section{R-927 $\alpha$. Arslantepe D8(8) A58}

Charcoal from double hearth in $\mathrm{Rm} 58$, Sq D8-8.

\section{R-928 $\alpha$. Arslantepe D8(8)-E8(5) A58}

Charcoal from floor of Rm 58, Balk D8(8)-E8(5).

General Comment: dates refer to a room with central double hearth built on terraced area cutting final Early Bronze levels. Pottery with plastic decoration. Local aspect to be correlated to old Hittite, dated at Korucu Tepe, Middle Bronze II, 3320 to 3160 вр, see P-1613/14 -16 -27 (R, 1971, v 13, p 368-369); GrN-6057, $3250 \pm 35$ (Van Loon, 1973).

$V$ Arslantepe period, recent phase, Late Bronze I, NE area, 1969 \& 1971

\section{R-724 $\alpha$. Arslantepe C3(F1) A66 Vb}

$\mathbf{3 2 2 0} \pm \mathbf{5 0}$

$1270 \mathrm{BC}$

$\delta^{13} C=-22.3 \%$

Charcoal inside pot in Rm 66, Zone C3(F1), Level Vb, 1969.

\section{R-725 $\alpha$. Arslantepe C3(F1) A67 Vb}

$$
\begin{gathered}
2970 \pm 50 \\
1020 \text { BC } \\
\delta^{13} C=-26.0 \%
\end{gathered}
$$

Charcoal from filling of Rm 67, Zone C3(F1), Level Vb, 1969. 


\section{R-726 $\alpha$. Arslantepe C3(F2) Vb}

Charcoal from floor of left tower of gate re-utilization, Zone C3(F2) Level Vb, 1969.

\section{R-924 $\alpha$. C3(F4) Vb}

Charcoal from floor, gate entrance $\mathrm{Vb}, 1971$.

General Comment: ${ }^{14} \mathrm{C}$ dates re-utilization, probably as dwelling, of 2Tower Gate. Rooms 66 and 67 cut out in earthen enclosure wall near gate. Pottery, Hittite type, comprising also red-on-buff painted ware. Aspect to be correlated with "Middle Hittite" (Middle Kingdom). Dating of Korucu Tepe, Late Bronze I, in Altinova: P-1615, $3244 \pm 59(\mathrm{R}, 1971$, v 13, p 369; Van Loon, 1973).

General Comment on Arslantepe: Arslantepe sequence is mainly comparable with that of Altinova, Keban Dam area. Series is consistent and agrees with ages of Korucu Tepe, similar cultural sequence. Available date of Arslantepe Imperial Gate, R-914, $2835 \pm 70$ (R, 1966, v 8, p 405-406) also agrees with Korucu Tepe Late Bronze II: P-1611, $2924 \pm$ 71 and P-1612, 2871 $\pm 63(\mathrm{R}, 1971$, v 13, p 368).

For correlations with historic dates, MASCA corrected ${ }^{14} \mathrm{C}$ dates are to be considered.

II. GEOLOGIC SAMPLES

\section{A. Italy}

\section{R-977. Candiolo}

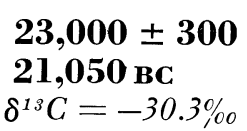

\section{R-977 $\alpha$. Candiolo}

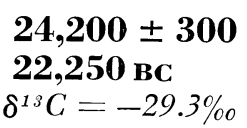

Sedge (Carex) peat from Level IV, Drilling P3, 1972, for FIAT at Ciabot near fosso Martinetto, NNE Comm Candiolo, prov Turin, Piedmont (44 $57^{\prime} 42^{\prime \prime} \mathrm{N}, 7^{\circ} 36^{\prime} 28^{\prime \prime} \mathrm{E}$ ) at $+237 \mathrm{~m}$. Coll by L Peretti 1972 and subm 1973 by G Charrier, both of Ist Giacim Min, Politecnico Turin. Pollen analysis of peat by G Charrier (written commun) shows herbaceous plants (Cyperaceae, Graminaceae, Compositae, Caryophyllaceae, Ephedra, Pteridophita) prevailing $(85 \%)$, on arboreal plant pollen (15\%) (Pinus cembra, Betula nana, Juniperus and very scarce Picea) absent Abies and mixed-forest trees. Comment: R-977 was pretreated with only $10 \% \mathrm{HCl}, \mathrm{R}-977 \alpha$ also leached with $.2 \mathrm{~N} \mathrm{NaOH}$. For the first time in $\mathrm{W}$ Po plain ${ }^{14} \mathrm{C}$ dates at Early Würm III, a vegetational complex typical of dry cold climatic phase; through pollen analysis data, Candiolo IV can be correlated with peat layers of Pleistocene series in W Po 
plain S Turin as at Vinovo, Carignano-La Loggia, Moncalieri, etc now under study (Charrier and Peretti, 1976).

\section{R-1022 $\alpha$. Fiume Adda, Formigara}

$1720 \pm 50$

Well preserved wood (Juglans regia) from very large trunk, diam $1.5 \mathrm{~m}$, buried in gravelly sandy sediments of Adda R stream-bed ca $1 \mathrm{~km}$

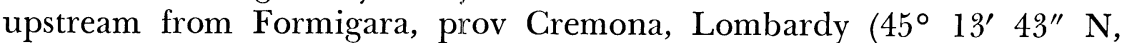
$9^{\circ} 46^{\prime} 04^{\prime \prime}$ E). Coll 1971 by local people and subm 1974 by G A Milanesi, Soresina. Comment: owing to extraction by suction of gravel and sand for commercial purposes, at times tree trunks (Quercus sp, Ulmus, Juglans, etc) are uncovered from river bed and used for firewood (Milanesi, written commun). ${ }^{14} \mathrm{C}$ age, the only available, approx dates an alluvial phase.

\section{R-951 $\alpha$. Misurina}

$4800 \pm 50$ $2850 \mathrm{BC}$

$\delta^{13} C=-25.5 \%$

Vegetable remains, mainly small darkened wood fragments (Abies alba, Larix decidua) id by F Lona, Ist Bot, Univ Parma (oral commun), from base of a slope wash at foot of mts surrounding Misurina Lake ca 20 to $30 \mathrm{~m}$ from SW shore, prov Belluno, Veneto $\left(46^{\circ} 34^{\prime} 39^{\prime \prime} \mathrm{N}\right.$, $\left.12^{\circ} 15^{\prime} 05^{\prime \prime} \mathrm{E}\right)$. Coll and subm 1972 by F Lona. Comment: wood dates Holocene event more recent than expected.

\section{R-1078 $\alpha$. Torrente Stirone}

$$
\begin{array}{r}
>\mathbf{4 2 , 0 0 0} \\
\delta^{13} C=-27.2 \% \%
\end{array}
$$

Classical Plio-Pleistocene thick series incised by Stirone torrent, ca

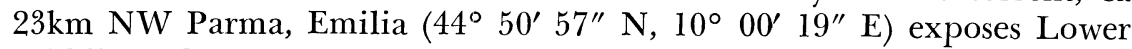
Middle and Upper Pliocene up to Calabrian interbedded marine sands, calcarenite and clay formations underlying Pleistocene lacustrine and continental deposits. Along river bed in Calabrian clays there are some stratigraphically anomalous erosion pockets filled by lacustrine deposits; the latter, though sedimentarily analogous to lacustrine normal series, cannot be correlated to this stratigraphically. Stratigraphic, micro- and macropaleontologic and paleoecologic revisions (Papani and Pelosio, 1962; Pelosio and Ratti, 1974), as well as paleomagnetic measurements (Bucha et al, 1974) of this series are being done. Fairly well preserved wood, large trunk of Conifera from upper lacustrine sediments in erosion pocket coll and subm 1974 by G Kukla, Columbia Univ, C Arias, and F P Bonadonna, both of Univ Pisa, and G Bigazzi, Lab Geochronol C N R, Pisa. Comment: $5 \% \mathrm{HCl}$ pretreatment shows wood devoid of carbonates, abundant $\mathrm{Fe}^{++}$and $\mathrm{SO}_{4}--.{ }^{14} \mathrm{C}$ minimum age refutes Main Würm and supports sedimentologic analogies for correlation between lacustrine deposits of pockets and lacustrine series. 


\section{R-1046. Cava Serrelle}

$$
\begin{gathered}
\mathbf{5 2 9 0} \pm \mathbf{5 0} \\
\mathbf{3 3 4 0} \mathbf{B C} \\
\delta^{1 s} C=-25.6 \%
\end{gathered}
$$

Well preserved wood, fragment of fossil trunk ca $2 \mathrm{~m}$ long (Pinus $\mathrm{sp}$, silvestris-montana group) id by M Follieri, Ist Bot, Univ Rome, (written commun) recovered from ca 15 to $20 \mathrm{~m}$ depth by suction pump with marine silica sand during work at Serrelle quarry, Comm Massarosa, coastal plain of Bassa Versilia, prov Lucca, Tuscany $\left(43^{\circ} 52^{\prime} 47^{\prime \prime} \mathrm{N}, 10^{\circ}\right.$ $14^{\prime} 06^{\prime \prime} \mathrm{E}$; U T M system PP 0325 5950) at $+2 \mathrm{~m}$. Coll and subm by D Pandolfi, Dist Min Carrara (Pandolfi, 1975). Comment: .2N NaOH pretreatment did not disclose humic material. At Serrelle dune and marine silica sand formation, ca $25 \mathrm{~m}$ thick, underlies upper peat layer, 2 to $4 \mathrm{~m}$ thick, and rests on interbedded sand and peaty clay levels. Similar stratigraphic series were recognized over vast area in Versilia coastal plain (A C Blanc, 1935, 1937; A C Blanc et al, 1953; Pandolf, 1975). Fossil trunk dates a Holocene Sub-Boreal cold climatic phase for Versilia plain, as already recognized (Tongiorgi, 1936); at present, species belonging to silvestris-montana group live over $+1000 \mathrm{~m}$ in Italy. ${ }^{14} \mathrm{C}$ age of shells (Purpura haemastoma L s sp consul) extracted by suction from marine silicia sand formation in Massaciuccoli Lake near Torre del Lago: Pi-116, $5650 \pm 220$ (R, 1961, v 3, p 104). For dating of upper peat layer and of a compressed peat pebble found in marine silica sand, both sampled by suction in Massaciuccoli Lake, see R-40-51 and R-39 (R, 1964, v 6, p 87-88 \& 1965, v 7, p 220).

\section{Torrente Saccione series}

Dark-grayish sandy clays and vegetable remains from cores of SM 6,8 , and 32, from $>50$, drillings made 1974 by Geosonda, Roma for ENEL along Adriatic coast, 2.3 to $1.3 \mathrm{~km}$ left side of Saccione torrent mouth, ca $14 \mathrm{~km} \mathrm{SW}$ Termoli, prov Campobasso, Molise $\left(41^{\circ} 55^{\prime} \mathrm{N}\right.$, $15^{\circ} 06^{\prime} \mathrm{E}$ ). Coll 1974 by R Gnisci, Geosonda, and subm 1974 by G Sestini and G Tirabassi for V Morelli, ENEL. Stratigraphic, sedimentologic, and micropaleontologic studies of some cores, 70 to $100 \mathrm{~m}$ long, were made (Chiocchini, 1975). From surface soil Holocene continental deposits and Pleistocene ones, latter both continental (fluvio-lacustrine and marshy) and marine (littoral and neritic) have been identified as 4 formations.

\section{R-1075. Saccione SM32}

$7900 \pm 60$

$$
5950 \mathrm{BC}
$$

$\delta^{13} \mathrm{C}=-27.3 \%$ o

Dark-gray sandy clay with many mollusk shells and no visible vegetable remains, from 13 to $13.30 \mathrm{~m}$ below top of SM32 core $\left(44^{\circ} 55^{\prime} 21^{\prime \prime} \mathrm{N}\right.$, $\left.15^{\circ} 07^{\prime} 06.2^{\prime \prime} \mathrm{E}\right)$ at $+3.98 \mathrm{~m}$. Comment: sample was pretreated with $10 \%$ $\mathrm{HCl}$ only. Date indicates Holocene time.

\section{R-1076a. Saccione SM6}




\section{R-1076b. Saccione SM6}

$7960 \pm 60$

$6010 \mathrm{BC}$

$\delta^{13} \mathrm{C}=-27.0 \%$

Dark-grayish sandy clay with mollusk shells and scarce small vegetable remains, from 16 to $16.30 \mathrm{~m}$ below top of SM6 core $\left(41^{\circ} 55^{\prime} 31^{\prime \prime} \mathrm{N}\right.$, $\left.15^{\circ} 07^{\prime} 13.9^{\prime \prime} \mathrm{E}\right)$ at $-2.74 \mathrm{~m}$. Comment: samples pretreated with $10 \%$ $\mathrm{HCl}$ only. R-1076a had almost no shells; R-1076b was full of shells. Dates agree and indicate Holocene time as expected.

R-1077a $\alpha$. Saccione SM8

$$
\begin{array}{r}
>\mathbf{4 2 , 0 0 0} \\
\delta^{13} C=-27.0 \% \\
>\mathbf{4 2 , 0 0 0} \\
\delta^{13} C=-27.4 \% \\
>\mathbf{4 2 , 0 0 0} \\
\delta^{13} C=-27.3 \% \circ
\end{array}
$$

\section{R-1077a. Saccione SM8}

R-1077b. Saccione SM8

Dark-grayish sandy clay with mollusk shells and darkened wood remains, ranging in size from tiny to many $\mathrm{cm}$, from 69.50 to $70.30 \mathrm{~m}$ below top of SM8 core $\left(41^{\circ} 55^{\prime} 27.6^{\prime \prime} \mathrm{N}, 15^{\circ} 06^{\prime} 24.8^{\prime \prime} \mathrm{E}\right)$. Comment: R-1077a $\alpha$, largest wood fragments separated by hand: $5 \% \mathrm{HCl}$ pretreatment and additional leaching with .2N NaOH; R-1077a, smaller wood fragments recovered by wet sieving, $2 \mathrm{~mm}$ mesh; R-1077b, dark-grayish sandy clay fraction freed from wood by wet sieving, $2 \mathrm{~mm}$ mesh: pretreatment only with $5 \%$ HCl. Three minimum ages agree and refute Würm III and Main Würm.

General Comment: 3 dates requested for geotechnical purposes, to check compaction and stabilization of coastal terrains, are inadequate for geologic study of zone.

\section{B. Procida Island}

The following series include systematic dates of carbonized wood and humified layers of paleosols interbedded in pyroclasts of ProcidaVivara Is, Tyrrenian Sea, divided by Procida channel, $3 \mathrm{~km}$ average width, from Campanian coast facing Campi Flegrei dist, NW Naples $\left(40^{\circ} 45^{\prime}\right.$ $\mathrm{N}, 14^{\circ} 00^{\prime} \mathrm{E}$ ). Procida-Vivara volcanic dist comprises several volcanic vents and was formed by autochthonous pyroclasts of both submarine and subaereal origin (Di Girolamo \& Stanzione, 1973). Volcanic activity on island ended with Volcano VII-Solchiaro eruption; later Procida was covered by tephra from nearby Campi Flegrei volcanos, probably from vents at Fondi di Baia, though definite stratigraphic correlation between 2 volcanic districts is still lacking (Rittmann, 1951; Di Girolamo \& Stanzione, 1973). Carbonized wood and humified layers, sampled in cliff sections exposed along Procida-Vivara coasts, are interbedded in stratigraphically significant pyroclastic formations. All visible contaminants (rootlets, etc) were removed by hand. Sample pretreated with $8 \mathrm{~N} \mathrm{HCl}$, humic acids extracted with $.2 \mathrm{~N} \mathrm{NaOH}$ and precipitated again by dilute HCl. Coll and subm by P Di Girolamo, Ist Min, Univ Napoli and by G Calderoni and U Nonno, both of Ist Geochimica, Univ Rome. 


\section{Procida, Sancio Cattolico series}

Sec, ca $20 \mathrm{~m}$ thick, in Sancio Cattolico cliff ca $500 \mathrm{~m}$ E Procida 1 harbor, NE coast $\left(40^{\circ} 45^{\prime} 52^{\prime \prime} \mathrm{N}, 14^{\circ} 02^{\prime} 07^{\prime \prime} \mathrm{E}\right)$ exposes from top: a) Phlegrean tephra, $6 \mathrm{~m}$ thick, with embedded humified layer, covering whole Procida-Vivara area, separated by humified layer from underlying b) bedded trachybasalt hyaloclastite of Vulcano VII-Solchiaro, latter the most widespread of autochthonous formations; c) cinder pyroclasts "Formazione 12", $8 \mathrm{~m}$ thick, comprising over 3 humified layers, also guidelevel largely widespread in I.

\section{R-1052. Sancio Cattolico 1}

$$
\begin{gathered}
6220 \pm 70 \\
4270 \text { BC } \\
\delta^{13} C=-25.6 \%
\end{gathered}
$$

Humic acids $(0.2 \%)$ from humified layer, $40 \mathrm{~cm}$ thick, embedded in middle part of Phlegrean tephra.

\section{R-1053. Sancio Cattolico 2}

$14,100 \pm 150$

$12,150 \mathrm{BC}$

$\delta^{13} \mathrm{C}=-25.8 \%$

Humic acids $(0.4 \%)$ from humified layer, $60 \mathrm{~cm}$ thick, underlying Phlegrean tephra and overlying Solchiaro stratified hyaloclastite.

\section{R-1054. Sancio Cattolico 3}

$19,620 \pm 270$

$17,670 \mathrm{BC}$

$\delta^{13} \mathrm{C}=-25.6 \%$

Humic acids $(1.1 \%)$ from upper humified layer, $40 \mathrm{~cm}$ thick, in cinder pyroclasts "Formazione 12", immediately underlying Solchiaro stratified hyaloclastite.

\section{R-941. Sancio Cattolico 4 \\ $25,200 \pm 400$ \\ 23,250 BC \\ $\delta^{13} C=-25.2 \%$}

Humic acids $(0.1 \%)$ from humified layer, $30 \mathrm{~cm}$ thick, embedded in middle part of cinder pyroclasts "Formazione 12".

\section{R-1055. Sancio Cattolico 5}

$28,850 \pm 860$

26,900 BC

$\delta^{13} \mathrm{C}=-25.9 \%$

Humic acids $(1.0 \%)$ from humified layer, $50 \mathrm{~cm}$ thick, at base of cinder pyroclasts "Formazione 12".

General Comment: dates of humified layers cropping out in Sancio Cattolico cliff are consistent. R-1053 dates within 14,100 вP end of eruptions in Procida I. Subsequent fall of Phlegrean tephra, id as 2nd and 3rd period products (see: R, 1971, v 13, p 405-409, \& 1973, v 15, p 173176), shows a significant interruption at ca 6200 вP according to R-1052. R-1054 dates at ca 19,600 вр the only, though notable, Solchiaro eruption. Finally, R-1054, -941, \& -1055 date from ca 19,000 to 30,000 вP outcrop of widespread "Formazione 12" of still uncertain origin. 


\section{Procida, Fiumicello series}

Sec, ca $25 \mathrm{~m}$ thick, in Fiumicello cliff, $\mathbf{N}$ coast Procida I (40 $46^{\prime} 05^{\prime \prime}$ $\mathrm{N}, 14^{\circ} 00^{\prime} 46^{\prime \prime} \mathrm{E}$ ) exposes from top: a) Phlegrean tephra; b) hyaloclastite of Solchiaro; c) cineritic "Formazione 12" containing paleosols; d) Vulcano IV pyroclasts; e) humified layer, $1.5 \mathrm{~m}$ thick; f) Vulcano III-Fiumicello stratified tuff.

\section{R-1050. Fiumicello A \\ $26,700 \pm 500$ \\ 24,750 вС \\ $\delta^{13} \mathrm{C}=-25.4 \%$}

Humic acids $(0.5 \%)$ from upper level of humified layer, $1.5 \mathrm{~m}$ thick, underlying Vulcano IV pyroclasts.

\section{R-1051. Fiumicello B}

$29,000 \pm 800$ 27,050 вС

$\delta^{13} \mathrm{C}=-26.4 \%$

Humic acids $(0.2 \%)$ from lower level of humified layer, $1.5 \mathrm{~m}$ thick, underlying Vulcano IV pyroclasts.

General Comment: dates Vulcano IV explosion whose products, mainly welded scoriae and pumice tuffs, extend to NE area of Procida I. Difference between 2 dates indicate soil evolution before burial.

\section{Vivara Island}

Small Vivara I, SW Procida, minimum distance ca $100 \mathrm{~m}\left(40^{\circ} 44^{\prime}\right.$ $33^{\prime \prime} \mathrm{N}, 13^{\circ} 59^{\prime} 38^{\prime \prime} \mathrm{E}$ ) is well-preserved crater relict of Vulcano I-Vivara that erupted trachybasalt hyaloclastite, oldest formation cropping out in Procida-Vivara dist. Sec, $20 \mathrm{~m}$ thick, at La Carcara, E coast Vivara $\left(40^{\circ}\right.$ $44^{\prime} 43^{\prime \prime} \mathrm{N}, 13^{\circ} 59^{\prime} 42^{\prime \prime}$ E) exposes from top: a) Phlegrean tephra; b) Vulcano VII-Solchiaro hyaloclastite; c) pumices interbedded in ash layers, partly belonging to Vulcano I-Vivara, and overlying hyaloclastite from same volcano.

\section{R-967 $\alpha$. Vivara, La Carcara}

$$
\begin{aligned}
& 40,000 \pm 4000 \\
& \mathbf{3 8 , 0 5 0} \text { BC } \\
& \delta^{13} C=-24.6 \%
\end{aligned}
$$

Carbonized wood from pumices embedded in ash layers, at La Carcara E coast of Vivara. Comment: R-967 $\alpha$ dates last eruptions of Vivara volcano.

General Comment: dates of humified layers and carbonized wood are stratigraphically consistent and date from ca 44,000 to 14,000 вP the volcanic activity in Procida-Vivara dist from last eruptive phases of oldest outcropping Vivara volcano to Solchiaro eruption; Vulcano IV explosion was also dated at ca 27,000 вр. Ages of Phlegrean tephra cover indicate products belonging to 2nd and 3rd periods of Campi Flegrei volcanic activity. 
REFERENCES

Alessio, M, Bella, F, and Cortesi, C, 1964, University of Rome carbon-14 dates II: Radiocarbon, v 6, p 77-90.

Alessio, $\mathrm{M}$ et al, 1965, University of Rome carbon-14 dates III: Radiocarbon, $\mathrm{v} 7$, p 213-222.

1966, University of Rome carbon-14 dates IV: Radiocarbon, v 8, p 401-412. 1967, University of Rome carbon-14 dates V: Radiocarbon, v 9, p 346-367. 1968, University of Rome carbon-14 dates VI: Radiocarbon, v 10, p 350-364. 1969, University of Rome carbon-14 dates VII: Radiocarbon, v 11, p $482-498$. 599-616. 1970a, University of Rome carbon-14 dates VIII: Radiocarbon, v 12, p

1970b, Report on the equipment and activities of the Rome University's carbon-14 dating laboratory: Quaternaria, v 13, p 357-376.

1971, University of Rome carbon-14 dates IX: Radiocarbon, v 13, p 395-411.

1973, University of Rome carbon-14 dates X: Radiocarbon, v 15, p 165-178. 313-327.

Azzi, C M, Bigliocca, L, and Piovan, E, 1973, Florence radiocarbon dates I: Radiocarbon, v 15, p 479-487.

1974, Florence radiocarbon dates II: Radiocarbon, v 16, p 10-14.

Bartolomei, G, 1966, Diagramma microfaunistico con Sicista della Grotta della Ferrovia nella "Gola della Rossa" del fiume Esino presso Iesi (Ancona): Università di Ferrara Annali, n s, Sezione IX, v 4, no. 5, p 69-75.

Bernabò Brea, L, 1965, Segnalazione di rinvenimenti paleolitici in Sicilia: Paletnol Italiana Bull, v 74, p 7-22.

Biddittu, I, 1967-68, Rinvenimenti preistorici in provincia di Frosinone: Ist Storia Arte del Lazio meridionale Boll, v 5, p 5-17.

1973, Insediamenti del Paleolitico superiore: in Club Alpino ItalianoSez Frosinone: Proposta per una riserva naturale dei Monti Ernici, TrisultiMonna-Monte Prato, p 32-36.

Bietti, A, 1976, Analysis and illustration of the Epigravettian industry collected during the 1975 excavations at Palidoro (Rome, Italy): Quaternaria, v 19, in press.

Blanc, A C, 1935, Formazioni pleistoceniche nel sottosuolo della Versilia (Nota preliminare): Soc Toscana Sci Nat Processi Verbali, v 43, no. 5, p 1-17.

1937, Low levels of the Mediterranean Sea during the Pleistocene glaciation: Quart Jour Geol Soc, v 93, p 621-651.

1955, Giacimenti del Paleolitico superiore ad Equus hydruntinus e sovrapposti livelli con ceramica neolitica (?) e dell'età del Bronzo nella Cava di travertino di Palidoro (Roma): Quaternaria, v 2, p 309-310.

Blanc, A C, Settepassi, F, and Tongiorgi, E, 1953, Excursion au Lac de Massaciuccoli (Plane Côtière de la basse Versilia): INQUA IV Congrès Internatl Rome-Pisa 1953, Livret-guide.

Bradford, J S P, 1957, Ancient landscapes studies in field archaeology: London.

Braidwood, R J, and Braidwood, L S, 1960, Excavations in the Plain of Antioch: Oriental Inst pubs, v 61, Chicago.

Bucha, V, Horacek, J, Koci, A, Sibrova, V, and Lozev, V, 1974, Paleomagnetic correlations of pleistocene sediments of Central Europe: in I G C P Project $73 / 1 / 24$ Quaternary glaciations in the Northern Hemisphere-Report no. 2 Salzburg (Austria) Sept 1974, p 9-36.

Burchuladze, A A, 1968, Tbilisi radiocarbon dates I: Radiocarbon, v 10, p 466-467.

Burney, C and Lang, D M, 1971, The peoples of the hills: Weidenfeld and Nicolson ed, London.

Cardini, L, 1969, Lo scavo del Peschio Ranaro a Collepardo (Frosinone): Quaternaria, v 11, p 284-285.

1971, Rinvenimenti paleolitici nella Grotta Giovanna (Siracusa): XIII Riunione Sci Ist Italiano Preistoria e Protostoria, Siracusa-Malta ottobre 1968 Atti, p 29-35.

Cassoli, P F, 1976, The faunae of the 1955 excavations at Palidoro (Rome, Italy): Quaternaria, v 19, in press.

Castaldi, E, 1969, Tombe di Giganti nel Sassarese: Origini, v 3, p 119-274. 1975, Domus nuragiche: De Lucia ed, Roma. 
Charrier, G and Peretti, L, 1976, Ricerche sull'evoluzione del clima e dell'ambiente durante il Ouaternario nel settore delle Alpi Occidentali italiane: VI-Documenti stratigrafici del Würm III nella Pianura Padana occidentale sulla base di reperti pollinici e di datazioni radiometriche ${ }^{14} \mathrm{C}$ : Alliona, $v$ 22, in press.

Chiappella, V, 1965, Scavo nel giacimento paleolitico superiore di Palidoro (Roma): Quaternaria, v 3, p 263-264. $\mathrm{v} 5, \mathrm{p} 338$.

Chiocchini, M, 1975, Relazione sullo studio micropalcontologico e stratigrafico di sondaggi eseguiti dall'ENEL nella zona del litorale fra Campomarino c Chicuti (Molise): mimeo Report.

Club Sommozzatori Padova-Sez Archeol, 1976, Recupero di piroghe preistoriche a Selvazzano (Padova): Com Italiano Ricerche e Studi Subacquei, I Simposio Naz Atti, Roma 11-12 ottobre 1974, p 80-83.

Contu, E, 1966, Oridda (Sennori): Riv Sci Preistoriche, v 21, p 437-438.

1972a, Sa Turricula (Muros): Riv Sci Preistoriche, v 27, p 473. 473-474.

1972b, Su Crucifissu Mannu (Portotorres): Riv Sci Preistoriche, v 27, p

Cornaggia Castiglioni, O, 1971, La Cultura di Civate-Una nuova facies arcaica della Civiltà eneolitica in Lombardia: Natura, v 62, no. 1, p 101-125.

Cornaggia Castiglioni, $O$ and De Michele, E, 1963, Le incisioni parietali del Buco della Sabbia di Civate (Como): $7^{\mathrm{a}}$ Riunione Sci Ist Italiano Preistoria e Protostoria Atti, p 45-57.

Corona, E, 1974a, Dendrocronologia, radiocarbonio e palinologia del Colosseo: Italia Forestale e Montana, v 29, p 11.7-118. Report. $1974 b$, Reperto R-858 della Basilica Emilia al Foro Romano: mimeo

Corrain, C and Cornaggia Castiglioni, O, 1964, I resti scheletrici umani del Buco della Sabbia di Civate: Soc It Sci Naturali Atti, v 103, p 74-82.

Cozza, L, 1975, I recenti scavi delle Sette Sale: Pont Acc Romana Archeol Rend, in press.

Crane, H R and Griffin, I B, 1972, University of Michigan radiocarbon dates XV: Radiocarbon, v 14, p 195-222.

Delaporte, L, 1940, Malatya; fouilles de la mission archéologique française. ArslantepeLa Porte des Lions: Paris.

Delibrias, G, Guillier, M T, and Labeyrie, J, 1966, Gif natural radiocarbon measurements II: Radiocarbon, v 8, p 74-95.

Di Girolamo, P and Stanzione, D, 1973, Lineamenti geologici e petrologici dell'isola di Procida: Soc Italiana Miner Petrol Rend, v 29, p 81-125.

D’Onorio De Meo, G, 1975, La Vergine Incoronata di Foggia, Edizioni "Santuario dell'Incoronata", Foggia.

Esin, U, 1972, Tepecik Excavations, 1970: Keban Projesi 1970 Calismalari, Ankara, p 149-158.

Ferrara, G, Fornaca Rinaldi, G, and Tongiorgi, E, 1961, Carbon-14 dating in Pisa-II: Radiocarbon, v 3, p 99-104.

Ferrarese Ceruti, M L, 1972, La tomba XVI di Su Crucifissu Mannu e la cultura di Bonnanaro: Paletnol Italiana Bull, v 81 , in press.

Ferri-Ricchi, L, 1974, Subacquei nel Colosseo-Fra i meandri sommersi: Mondo Sommerso, v 16, no. 1, p 69-71.

Follieri, M, 1973, Cereali del villaggio neolitico di Passo di Corvo (Foggia): Ann Botanica, v 32, p 49-58.

Gambassini, P, 1970, Risultati della campagna di scavi 1964 nel Riparo C delle Cipolliane (Lecce): Riv Sci Preistoriche, v 25, p 127-181.

Hauptmann, H, 1972, Die Grabungen auf dem Norsun-Tepe, 1970: Keban Projesi 1970 Calismalari, Ankara, p 103-117.

1974, Die Grabungen auf dem Norsun-Tepe, 1971: Keban Projesi 1971 Calismalari, Ankara, p 87-97.

Helms, S, 1973, Taskun Mevkii 1970-71, in: French, D et al, Asvan 1968-1972: Anatolian Studies, v 13, p 109-420.

Kushnareva, K and Chubinishvili, T, 1970, Ancient cultures of Southern Caucasus, Leningrad, in Russian.

Laplace, G, 1964a, Les subdivisions du Leptolithique italien. Etude de typologie analytique: Paletnol Italiana Bull, v 73, p 25-63. 
Laplace, G, 1964b, Essai de typologie systematique: Università di Ferrara Ann n s XV, suppl II, v 1, p 1-86.

1966, Recherches sur l'origine et l'évolution des complexes leptolitiques: Ecole Française de Rome, Mem d'Archeol et d'Histoire, Suppl 4. 1968, Recherches de typologie analytique: Origini, v 2, p 7-64.

Lawn, B, 1971, University of Pennsylvania radiocarbon dates XIV: Radiocarbon, v 13 p 363-377. p $367-387$.

1973, University of Pennsylvania radiocarbon dates XV: Radiocarbon, v 15, 1974 $16, \mathrm{p} 219-237$.

Lilliu, G, 1963, L'architettura nuragica (Relazione generale): Congresso Storia dell' Architettura (Sardegna) Atti, Cagliari, 6-12 Aprile 1963, v 1, p 17-92.

1967, La civiltà dei Sardi dal Neolitico all'età dei Nuraghi: ERI-Edizione RAI, Radiotelevisione italiana 2nd ed, Torino.

Lunz, R, 1973, Ur- und Frühgeschicte Südtirols: Edizioni Athena, Bolzano. Malavolti, F, 1948, Fondi di capanna eneolitici a Ponte d'Idice: Emilia preromana, v 1,
p 43-44.

Mondello, R, Levanti, A, and Mazzolai, A, 1977, Studio antropologico su segmenti scheletrici di origine etrusca reperiti nel Grossetano: Studi Etruschi, v 45, in press.

Orthmann, W, 1963, Die Keramik des Frühen Brozezeit aus Inneranatolien: Gebr Mann Verlag, Berlin.

Palma di Cesnola, A, 1962, Contributi alla conoscenza delle industrie epigravettiane nell'Italia centromeridionale: Riv Sci Preistoriche, v 17, p 1-75.

1967, Il Paleolitico delle Puglie (Giacimenti, periodi, problemi): Mus Civico Storia Naturale Verona Mem, v 15, p 1-84.

Palma di Cesnola, A and Borzatti von Löwenstern, E, 1962, Marina di Novaglie il Ciolo (Com di Corsano): Riv Sci Preistoriche, v 17, p 287-288.

Palmieri, A, 1969, Recenti dati sulla stratigrafia di Arslantepe: Origini, v 3, p 7-66. 1970, Two years of excavations at Arsiantepe (Malatya): Türk Arkeoloji
v 19, no. 2, p 203-21l. Dergisi, v 19, no. 2, p 203-211.

1973, Scavi nell'area Sub-occidentale di Arslantepe. Ritrovamento di una struttura templare dell'antica età del Bronzo: Origini, v 7, p 55-228. 1974, Arslantepe (Malatya). Report on the excavations 1971-72: Türk Arkeoloji Dergisi, v 21, no. 1, p 137-146.

Pandolfi, D, 1975, La sabbia silicea della Bassa Versilia e i suoi impieghi: S E A, Carrara.

Papani, G and Pelosio, G, 1962, La serie Plio-Pleistocenica del T Stirone (Parmense occidentale): Soc Geol Italiana Boll, v 81, no. 4, p 293-335.

Pecorella, P E, 1975, Malatya III: Orientis Antiqui Collectio XII, Roma.

Pelliccioni, G, 1973, Le nuove scoperte sulle origini del Battistero Lateranense: Pontificia Acc Romana di Archeol Atti, s III Mem, v 12, no. 1, p 7-114.

Pelosio, G and Ratti, S, 1974, Osservazioni su Arctica islandica ed altri lamellibranchi del Calabriano dell'Emilia occidentale: Ateneo Parmense Acta Nat, v 10, p 347-367.

Pianese, S M, 1968, Rassegna storica degli studi e delle ricerche sul Paleolitico in Sicilia: Quaternaria, v 10, p 213-250.

Picozzi, S, 1974, Il collettore del Colosseo: Capitolium, v 49, no. 12, p 13-23.

Porada, Edith, 1965, The relative Chronology of Mesopotamia; Part I: in Erich, R W, ed, Chronologies in old World Archaeology: The University of Chicago Press, Chicago.

Puglisi, S M and Meriggi, P, 1964, Malatya I: Orientis Antiqui Collectio III, Roma.

Ralph, E K, 1959, University of Pennsylvania radiocarbon dates III: Radiocarbon, v 1 , $\mathrm{p}$ 45-58.

Ralph, E K, Michael, H N, and Ham, M C, 1973, Radiocarbon dates and reality: MASCA newsletter, v 9, p 1-20.

Rittmann, A, 1951, Cenni sulla Geologia di Procida: Soc Geol Ital Boll, v 70, p 533-544.

Scarani, R, 1963, Repertorio di scavi e scoperte dell'Emilia e Romagna: in: Deputazione Storia Patria per le Provincie di Romagna, Preistoria dell'Emilia e Romagna IIDocumenti e Studi, v 8, Ed Forni, Bologna.

Schneider Equini, E, 1970, Malatya II: Orientis Antiqui Collectio X, Roma.

Stuckenrath, R Jr, 1963, University of Pennsylvania radiocarbon dates VI: Radiocarbon, v 5, p 82-103. 
Stuckenrath, R Jr and Lawn, B, 1969, University of Pennsylvania radiocarbon dates XI: Radiocarbon, v 11, p 150-162.

Tauber, H, 1960, Copenhagen natural radiocarbon measurements III, corrections to radiocarbon dates made with the solid carbon technique: Radiocarbon, v 2, 1960, p 5-11.

Tiné, S, 1968, Lo scavo di una capanna del villaggio neolitico di Passo di Corvo: XI and XII Riunione Sci Ist It Preistoria e Protostoria, Firenze febbraio 1967 and Sicilia ottobre 1967, Atti, p 169-172.

1972, Gli scavi del villaggio neolitico di Passo di Corvo: XIV Riunione Sci Ist It Preistoria e Protostoria, Puglia ottobre 1970, Atti, p 313-331.

1975a, La civiltà neolitica del Tavoliere (Relazione generale)-Discussione: Colloquio Internazl Preistoria e Protostoria della Daunia, Foggia aprile 1973, Atti, p 99-111 and 173-196.

$1975 \mathrm{~b}$, Passo di Corvo, Ausgrabungen in einem neolitischen Dorf auf dem Tavoliere della Puglia: Antike Welt, v 3, p 27-32.

Tongiorgi, E, 1936, Le variazioni climatiche testimoniate dallo studio paleobotanico della serie flandriana nella pianura della Bassa Versilia presso il Lago di Massaciuccoli: Nuovo Giorn Botarico Italiano n s, v 43, p 762-774.

Van Loon, M, 1973, The excavations at Korucutepe, Turkey, 1968-70, Preliminary Report, Part I: Jour of Near Eastern Studies, v 32, no. 4, p 357-423.

Vogel, J C and Waterbolk H T, 1972, Groningen radiocarbon dates X: Radiocarbon v 14, p 6-110. 